\title{
The shape of the nation: Visual production of nationalism through maps in Turkey
}

\author{
Bülent Batuman* \\ Department of Urban Design and Landscape Architecture, Bilkent University, 06800 Ankara, Turkey
}

Keywords:

Maps and politics

Nationalism

Popular cartography

Appropriated maps

\begin{abstract}
A B S T R A C T
Nationalism, as a political discourse requiring a fundamental connection to a particular territory has constantly referred to maps as evidence of the eternal existence of the respective nation. In the case of modern Turkey, the national map has been a symptomatic signifier of a constant anxiety of territorial loss. Built around such anxiety, Turkish nationalism has been sensitive towards the borders defining national territory. This article analyzes the use of national maps as instruments for the cultural production of nationalism in Turkey throughout the last three decades. In the process, it is intended to differentiate between official maps produced under state authority and popular maps circulated in mass media.

Throughout the 1980s, national maps included in school textbooks presented a country surrounded by hostile neighbors on all sides, in tune with the political climate of the Cold War. A crucial aspect of these official maps was the cartographic awareness they generated which, in the following decade, would become operational in the widespread use of the map as a nationalist sign. With the emergence of the Kurdish question in the 1990s, the national map became a key instrument in promoting nationalist sentiments with the invention of the flag-map logo as a favorite symbol. After the US-led invasion of Iraq in 2003, the Kurdish issue was projected on to Northern Iraq, and a new mode of cartographic representation was invented. "Appropriated maps" produced through the digital retouching of random maps found on the Internet visualized irredentist desires enlarging the country's territory especially into Northern Iraq and invoking the Ottoman past. These maps, which consciously distorted geographical information, turned to historical references to sustain their cartographic validity.
\end{abstract}

(c) 2010 Elsevier Ltd. All rights reserved.
On August 7th 2006, the Turkish newspaper Cumhuriyet reprinted a map that was originally produced by the retired US military officer Ralph Peters and which had been published in the June 2006 issue of the Armed Forces Journal. The map, which depicted an imaginary Middle East as a solution to the political conflicts in the region, was originally coupled with another map showing the current situation in the Middle East. Entitled "Before" and "After", the two maps represented the existing borders and national territories with different colors (Fig. 1). The "After" map illustrated the arguments of the article redesigning the existing national territories and introducing new countries (Peters, 2006). For the Turkish media, the infuriating aspect of the map was not only the fact that Turkey was depicted as losing a significant amount of land in its eastern part, but that this land constituted a major portion of a "Free Kurdistan" together with land from Syria, Iran and Iraq. Cumhuriyet published the map in color on its first page with the headline "The Plan of Disintegration," attributing the map to the US Armed Forces. In addition, the newspaper published

\footnotetext{
* Tel.: +90 31229022 55; fax: +90 3122664053 .

E-mail address: bbatuman@gmail.com
}

both of the maps in larger format in a half-page article on its foreign news page (Cumhuriyet, August 7th 2006: 11). As Turkish-American relations were going through a severe crisis with Turkey's refusal to aid the US military in the occupation of Iraq in 2003, the map quickly became a symbol of a US conspiracy against Turkish national unity and triggered widespread protests.

Although the reaction of the Turkish public to this map - to which I will return below - is not surprising considering the ongoing armed struggle between the Kurdish separatists based in Northern Iraq and the Turkish state, it is significant that a fixation with national borders has been a constant element of Turkish political culture since the establishment of the republic in 1923. This was owing to the experience of the Ottoman Empire with ethnic revolts throughout the nineteenth century, the RussoTurkish War of 1877-1878, and the Balkan Wars of 1912-1913, which all together represented a continuous process of territorial decline that eventually ended up with total collapse at the end of World War I. The capital city of Istanbul as well as most of what was left in the Anatolian peninsula were occupied by the allied forces according to the Sevres Treaty of 1920 . Following the Turkish Independence War fought against the Greeks in 1919-1922, the borders of the newly established republic were agreed upon in the 

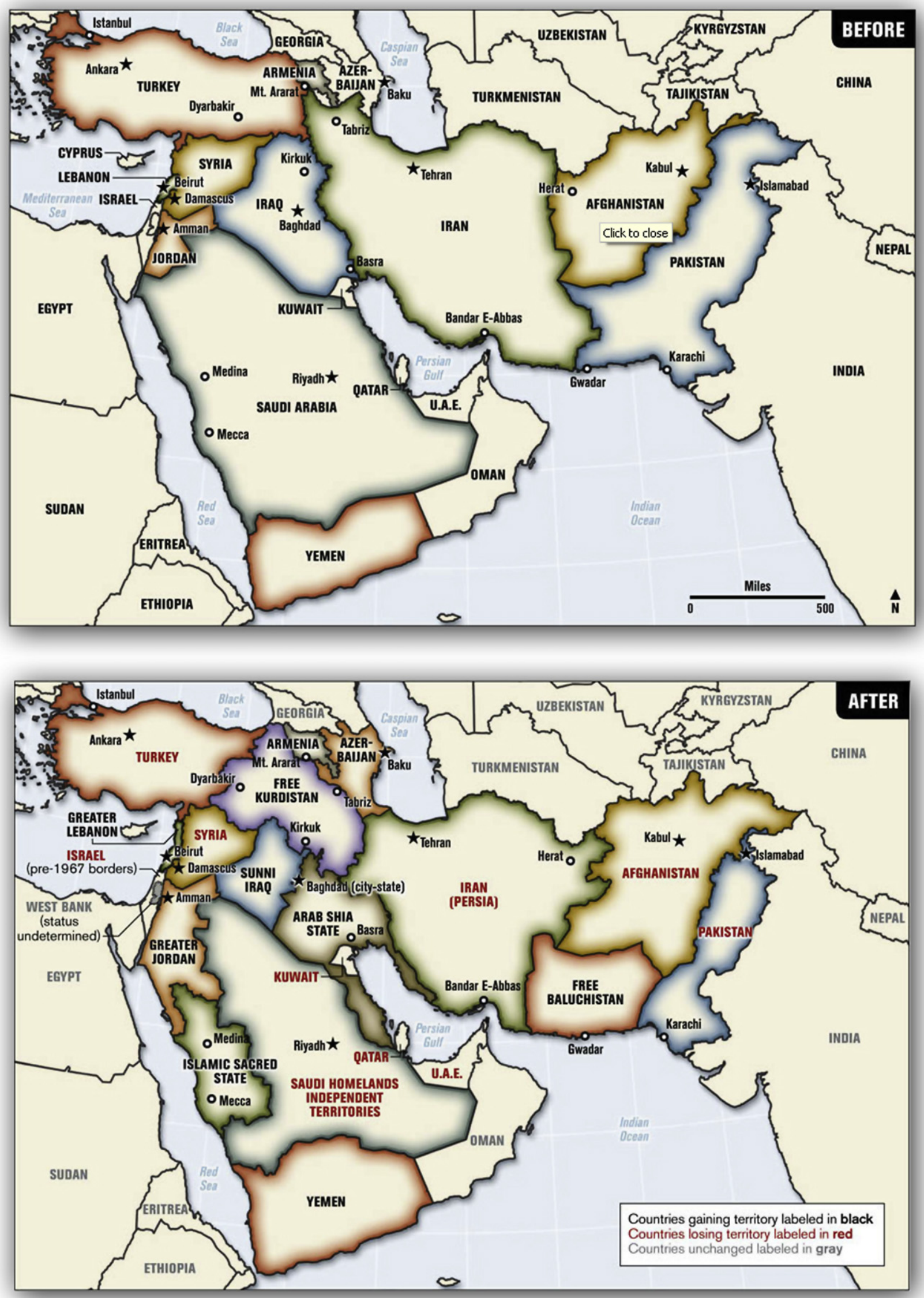

Fig. 1. The Middle East "Before” and "After" (Peters, 2006). 
Lausanne Treaty of 1923. From then on, a major component of Turkish nationalism has been a constant fear of an imperialist conspiracy aimed at disintegrating the nation, the major symbol of which was the Sevres Treaty. The building of a Turkish nation-state from the remnants of the multi-ethnic Ottoman Empire was pursued with particular hostility towards minorities. The nationalist elite that led the nation-building process in republican Turkey tended to suppress the ethnic differences within the country. As ideological support for this policy, the state bureaucracy was propelled by "the Sevres Syndrome", an irrational fear that the Western powers were constantly looking to dismantle Turkey in accordance with the Sevres Treaty (Guida, 2003; Robins, 2003: 161-180).

In this article, I intend to analyze the use of national maps as an instrument in the cultural production of nationalism in Turkey since the 1990s. This period is significant as it witnessed both the end of the Cold War and the escalation of the armed struggle for Kurdish independence, two major events that amplified the influence of nationalism as a political discourse in Turkey. Throughout this period, the use of the national map transformed not only the meanings the map embodied but also the agents of its production. My aim is to show that although the nation-state is a powerful agent in producing official maps and dominating the cartographic representations of the nation, other social actors are also capable of producing maps to disseminate their political views, especially with the help of digital technology and the availability of the Internet.

Here, I have three major intentions. The first concerns the relationship between official cartography and popular cartography. I argue that the popular perception of maps is also an effect of official maps; that is, the official maps not only transmit messages through cartographic representations, but they also produce a level of awareness regarding maps. As I discuss below, the emphasis put on national maps in primary and high school textbooks in the 1980s produced such an effect in Turkey and this was influential in the later widespread use of the national map. My second intention is to show that the masses are not merely the recipients of official and/or popular maps presented to them by the authorities. The production of maps in the form of cultural artifacts opened up possibilities for new meanings being attached to the maps, which stem from their use rather than from the intentions of their producers. A good example of this is the wide-scale and wide-ranging use of the Turkish map in the form of a logo in the 1990s. As the map is detached from the field of official cartography and reproduced as an image within popular culture, it becomes open to a new iconographic field through the new signs and symbols attached to it. Finally, I intend to expand the definition of "popular cartography", taking into consideration the maps produced by ordinary people. The availability of digital technologies and the Internet has allowed the average person to easily produce "appropriated maps" (by retouching existing ones) and circulate them, as illustrated by the ones produced by the Turkish ultra-nationalist Internet users in response to Peters' Middle East map. This type of cartographic production significantly broadens the definition of popular cartography since it transforms the practice of mapmaking, rendering any cartographic skill unnecessary.

Throughout the article I discuss examples of national maps produced in three periods. I use the maps included in the school textbooks in the 1980s as both examples of the cartographic representation of Turkey during the Cold War and as the origin of a cartographic awareness regarding the national map as a nationalist symbol. This aspect of the textbook maps is crucial since it illustrates the link between official mapping and popular (perception of) cartography. The wide-scale use of the map-logo in the 1990s builds on this foundation and allows the everyday use of the map in this new cultural form. In this period, the national map became a major instrument in reproducing nationalist sentiments in the face of the Kurdish question in Turkey. The favorite use of the map in popular culture was the flag-map logo superimposing the crescent-and-star of the Turkish flag onto the outline of the national territory. As I will show, this particular image itself unconsciously reproduced the very difference it served to suppress between the western and the eastern parts of the country, and the Kurdish identity of the latter. Finally, the publicity of the Peters map in Turkish newspapers triggered a wave of ultra-nationalist maps circulating on the Internet, which form the third set of maps that I study. These maps, which I call "appropriated maps", were produced by the reworking of existing maps through using various forms of software and visualized the irredentist desires of Turkish nationalists to enlarge the country's territory especially into Northern Iraq and invoking the Ottoman past.

It has to be underlined that each set of maps referred to in relation to these three periods has a different iconographic status. While the maps in the textbooks of the 1980s are official maps with a cartographic claim to scientific accuracy, the logo-maps of the 1990s are images detached from the field of official cartography and reproduced endlessly in various forms and media. The digitally produced and electronically circulated maps of the last epoch, on the other hand, have a totally different cartographic claim. This time the emphasis is not on the "truth" of the geographical situation but the desire to represent territorial claims backed by reconstructed historical evidence. I have used examples from a large number of maps that exist for each period and analyzed these examples with specific regard to the political iconography they embody.

\section{The map as a political tool}

Following the pioneering work of Harley (1988, 1989, 1990), various scholars have analyzed the relationship between power and cartographic representation. Referring to the work of Foucault, Harley has argued that the production of cartographic knowledge cannot be thought as independent from socio-political power relations. With an intrinsic claim to scientific accuracy, the map convinces the observer that what $\mathrm{s} /$ he sees is an objective representation of the geographical situation. In reality, what the map presents is a representation of the real situation, and as with every representation, the gap between the real and its representation is filled with power relations consumed within socially constructed meanings (Monmonier, 1996; Wood, 1992). That is, even the most "accurate" map inevitably gets caught up within power relations with what it shows as well as what it fails to show. Hence, the maps are discursive tools socially produced to persuade others (Pickles, 1992: 194).

The power of the map as a representational tool has been utilized towards maintaining political power and constructing identities. Claim to a particular land, whether it is in the form of a state's claim to a territory or a social group's attachment to its habitat, goes hand in hand with the production of representations supporting it (Peckham, 2000). State-produced maps have always been a particularly important instrument in maintaining authority on space and its inhabitants (Edney, 1997; Hu, 2007; Monmonier, 1996). Especially with the rise of nation-states, the map has emerged as a powerful sign of national unity and a cultural product materializing nationalist discourse. Nations as "imagined communities" have constantly referred to the shape of their territory as proof of their existence (Anderson, 1991: 170-178). Moreover, within the nationalist discourse, the homeland is always a historic land, which would serve as support for the historic memories and associations bringing people together and confirming the eternal 
existence of the nation (Smith, 1991: 8-10). Therefore, it becomes an essential task of nationalist discourses to maintain the link between nation and territory.

In this regard, maps have emerged as skillful tools for visually associating the nation with its homeland within the popular imaginary in the twentieth century (Anderson, 1991: 174-175). The presentation of the national territory in the form of maps within textbooks and atlases serves for the rationalization and naturalization of the relationship between the territory and the people provoking a sense of "territorial bonding" (Herb, 2004). In addition, it legitimizes the relationship between the state and territory emphasizing authority and possession. Nevertheless, the production of maps is not exclusive to the state, and the maps also act as products of popular culture, serving as a means of representing space (Culcasi, 2006; Kosonen, 1999). While "official mapping" dominated by state authority has been widely discussed, "popular cartography", that is, the maps designed for the masses and circulating in the mass media has remained less explored (Kosonen, 2008: 22).

The maps in school textbooks provide further interesting dimensions regarding the politics of cartographic representations. As Herb (2004) has argued, they are consumed at a crucial stage in the development of sociospatial knowledge. Because of this, cartographic representations in school textbooks have been widely utilized to support nationalist claims in different national contexts (Paasi, 1996: 145-151). Moreover, they exist at the intersection between official and popular cartography; although they reflect popular conceptions, they are produced by intellectual elites and their content is regulated by government agencies (Herb, 2004: 143). In this respect, national maps in school textbooks are a means for official cartography to influence popular cartography. Yet, the maps also have ideological consequences that surface in the longer run, in addition to their immediate effects (Helgerson, 1992: 107-147). As I will discuss in detail below, while these maps serve for the generation of a sense of attachment to the depicted territory, they also create a cartographic awareness. What is meant by cartographic awareness here is not consciousness regarding the iconography of maps or attentiveness towards the ideological meanings embedded in maps. It is rather familiarity with the map as a visual object. In the longer run, cartographic awareness leads to the perception of the map as an everyday image in the cultural sphere.

The widespread use of national maps as a cultural signifier of nationalism has to be understood in relation to banal nationalism (Billig, 1995). According to Billig, banal nationalism works through the unnoticed signifiers embedded within everyday life. His famous example is the "forgotten reminding" of the "national flag, hanging outside a public building or decorating a filling-station forecourt" in contrast to the "passionately waved flags" (Billig, 1995: 38). As I discuss below, the extensive circulation of the national map in Turkey functions similarly and disseminates banal nationalism.

\section{Mapping Turkey within the Cold War}

The trauma of the rapid territorial decline that marked the fall of the Ottoman Empire, and especially the experience of the First World War in which the Ottoman Empire allied with Germany and the Central Powers, continued to haunt the Turkish political imagination even after the founding of the Republic. Built around a sense of external threat (especially from the European powers) the constitutive discourse of Turkish nationalism based itself on exclusion and otherness (Bali, 2006; Özcan, 2006: 63-83). Within this discourse, especially the Greeks and the Arabs were conceived as hostile neighbors. The former were blamed for the military campaign they launched to invade Western Anatolia, and the latter for "betraying" the Ottoman Empire (the Caliphate) and collaborating with the British "infidels" during the World War. Yet the Kurds were the ones to most suffer such hostility, since they were the largest minority that was denied a nation-state under the postWWI status-quo. Kurdish territory, which was once a part of the Ottoman Empire, was partitioned into Turkey, Iraq (under British mandate) and Syria (under French mandate). As their claims for autonomy were disregarded during the WWI peace conferences, the Kurds revolted in the name of self-determination in the following decades. Between 1920 and 1938, the young Turkish State had to confront seventeen Kurdish rebellions, three of which (those in 1925, 1928 and 1938) were major (Özcan, 2006: 54-72). As a response to the recurring rebellions, the Turkish state deployed various assimilation strategies ranging from forced migration to military operations. Martial law, declared in the region in 1925, was not lifted until after WWII, and foreigners were not allowed to travel in the region until 1965 (Başkaya, 1991: 53). Nevertheless, the guerilla war launched by the PKK (Kurdistan Worker's Party) in 1984 proved to be the most troublesome one the Turkish republic has ever faced. The armed conflict between Kurdish separatists and government forces escalated especially after the First Gulf War in 1991 which created a power vacuum in Northern Iraq. Here, before analyzing the nationalist responses to the intensifying Kurdish question in the 1990s, I shall turn to the 1980s and discuss the utilization of nationalism as an antidote to the "communist threat" within the context of the Cold War.

During the Cold War, the hostility lying at the heart of Turkish nationalism towards Turkey's neighbors became geopolitically functional towards the Russians who were the eternal enemies of the Ottomans (the close solidarity between the republicans and the Soviet Union in the 1920s was quickly suppressed within official history) as well as the Bulgarians. Needless to say, the pro-Soviet Arab states of Syria and Iraq were also seen as threats. In addition to these, the ongoing dispute with Greece regarding the Aegean islands was escalated to the verge of armed conflict with Turkey's occupation of Northern Cyprus in 1974. Finally, with the Islamic Revolution in Iran in 1979, Turkey was under full siege by the 1980s. In the face of this constant threat, the Turkish nation had to be unified and stay in a state of alarm at all times. Especially after the military coup in 1980, which ruthlessly suppressed popular movements and implemented a new economic and political regime, a particularly xenophobic nationalism found its way into the educational system. The coup was one of many military interventions backed by the US against the "communist threat" throughout the Third World. The military regime saw the remolding of the educational system with a nationalist thread as a major component of the struggle against communism. In this context, school textbooks became a significant means of ideological indoctrination (Gürleyen, 1998).

The geopolitical imagination of Turkish nationalism, similar to other examples in various national contexts, reproduced itself through maps, particularly ones that were reproduced in school textbooks in the 1980s. Each and every classroom in elementary and high schools was required to have a national map hung on its walls. In addition, a decree regulating the formal qualities of textbooks also required the textbooks to include national maps (Ministry of Education, Youth and Sports, 1985: 9-13). Accordingly, all textbooks regardless of their subjects were required to include a portrait of Kemal Atatürk and the words of the national anthem in their first pages and a national map in their last page. Fig. 2 shows an example of such maps included in a high school textbook for Turkish Language and Literature (Birkan, 1988). In these maps, the rectangular form of the country - with a ratio of roughly $1: 2.5$ - fits into the $16 \times 24 \mathrm{~cm}$ standard textbook page with landscape layout on a scale of 1:10 million. The maps are always framed with bold 


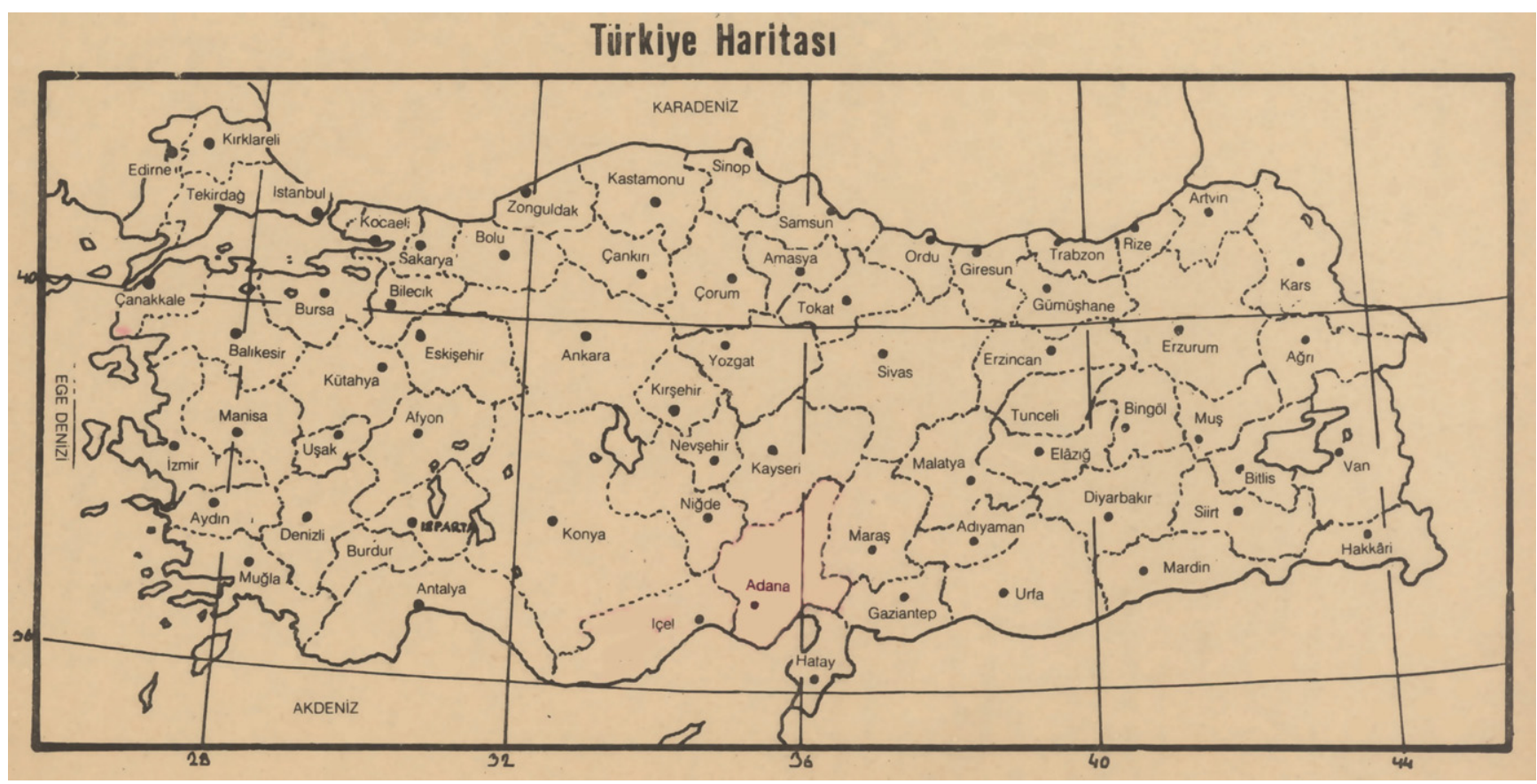

Fig. 2. “The Map of Turkey” (Birkan, 1988).

lines with the latitude and longitude numbers overflowing the frame. Such framing implies the objectivity of the map; the rectangular plane is cut out of the globe as witnessed by the latitudes and longitudes. In other words, the frame transforms the geographic place into an object of knowledge defined with a certain set of codes. The map in Fig. 2 shows the provinces of Turkey together with the cities that are provincial capitals. Other than these, the only information presented is the names of the seas surrounding the country. It is interesting to note that the shore lines and the continental borders are shown with the same line type. Neither the borders separating neighboring countries from each other nor the names of these countries exist in the map. Although there is minimal information regarding the exterior of the country, the provincial borders within the country are given with dashed (permeable) lines. The visual information on the provincial organization of the country suggests the existence of the nation-state within the map; the national territory is conceived within the order imposed on it by the state.

Yet these are not all there is to the map. The frame of the map is carefully drawn to include certain areas. Significantly, the Aegean islands, which belong to Greece, are shown in the map while mainland Greece is cut out. Depicted this way, the islands appear as located within the territorial waters of Turkey. In addition, the southern border of the map cuts the island of Cyprus into two, including the northern part under Turkish occupation and omitting the southern part. The desire to incorporate Cyprus into the national map and the reluctance to include the whole island, which is actually a sovereign state, resulted in the functioning of the map frame as an actual border marking Turkey's political claims regarding the island. Hence, the map frame does not only "objectively" carve out the country and its close surroundings, but also includes and omits certain features which gives an impression that the physical proximity of the territories included within the map is proof of Turkey's right to these territories.

In other versions, even if the maps provide more details, they deploy the same representational strategy. In some examples the seas are cross-hatched and the rivers are shown outreaching the national borders. In addition, some of the provinces are also shaded dark randomly in order to create a visual pattern. In spite of such details, the neighboring countries are never identified. When hatching is used, it also functions as an instrument of visualizing political disputes. The hatching of the seas brings the Aegean islands to the foreground making them extensions of mainland Turkey. Interestingly, in these examples northern Cyprus is also shaded, as if it is another province of Turkey.

The national maps, included in all textbooks published between 1985 and 1991, illustrate the dominant mode of cartographical representation of Turkey within primary and high-school education prior to the end of the Cold War. By means of these maps, pupils were required to identify with the national territory, represented not as a globally identifiable geographical location but as their own country. The lack of information regarding the exterior of the national borders was not merely an indifference towards other countries. The blank territories beyond national borders represented a constant unidentified threat, to which young pupils (as well as the whole nation) should always be attentive. The national territory itself was represented within a spatial order imposed by the state, visually reproduced by the provincial organization of the country. The students could recognize the province they lived in; a part of the whole which made the body of the country. Moreover, political disputes played a significant role within these maps, although they were presented quite subtly. The maps emphasized the physical proximity of the Aegean islands to mainland Turkey, and Cyprus was cut into two either by a border or at times by the map frame itself, perceptually attaching the northern half of the island to mainland Turkey.

Here, what is important for our discussion is the effect of the maps in school textbooks regarding the emergence of a certain level of cartographic awareness. The primary function of these maps was the visual production of a sense of nationhood among pupils. Yet, they also create familiarity with the map as a visual object. The cartographic awareness generated by the students' continuous exposure to the national map in the classroom space allows the students to perceive of the national map as a mundane 
image rather than a technical product of the specialized field of cartography. This, in turn, opens the possibility of the national map to be incorporated into the cultural repertoire of everyday life. This effect of the national maps in school textbooks is vital to the later emergence of the logo-map which I will discuss below. However, before going into the analysis of the map-as-logo, I shall discuss the transformation of official nationalism represented by the national maps in school textbooks after the end of the Cold War.

\section{Outward nationalism: discovery of Turks beyond borders}

The collapse of the Soviet Union and the emergence of Turkic states in Central Asia triggered a drastic shift in Turkey's foreign policy in the early 1990s. Turkey became the first state to recognize these new states formally and their presidents were invited to Turkey for a Turkic Summit in 1992 (Çelebi, 2006: 66). Trade relations were quickly established and funds allocated for investment in these countries. Such a move towards establishing close ties with these newly-born nations rested on an optimistic idea that Turkey could become the leader of the "Turkic world", and act as a model with its government system and market economy. Although this attempt to become the "big brother" of Turkic states would eventually fail within less than a decade, Turkish nationalists' hopes for the creation of a Turkic union under the leadership of Turkey found echo in the Turkish public as well (Uslu, 2003). This new foreign policy was coupled with an ideological campaign propagating the cultural ties of Turkey with Central Asia. A significant component of this campaign was the inclusion of maps of the "Turkic World" in school textbooks with a decree in 1993 (Ministry of Education, 1993a: 9). Together with the national maps, the textbooks were required to include a map showing the Turkic states as well as the geographical distribution of Turkic populations across Eurasia (Fig. 3).

In contrast to the national maps produced via a cylindrical projection (emphasizing the rectangular shape of the country), the "Turkic World" map incorporated into the textbooks was produced with a conical projection which centered on the Turkic states in Central Asia, more specifically Kazakhstan. The use of this conic projection presents Central Asia as the focus of the "Turkic World". In addition, it serves to minimize Europe, most of which is already left outside the map. The map also excludes South and East Asia, areas which would appear larger due to the use of the conic projection. Significantly, most of China is also hidden from the view with the legend located at the bottom right corner of the map. As the Turkic states of Central Asia lay at the center of the map, the Turkic populated territories compose a wide belt stretching from Siberia to Anatolia. The Turkic population scattered across the globe is shown in three different categories: independent states, autonomous territories and areas populated by Turks within other nation-states. Within the last category, even the guest workers in Europe are recorded. Depicted as such, the Turkic population

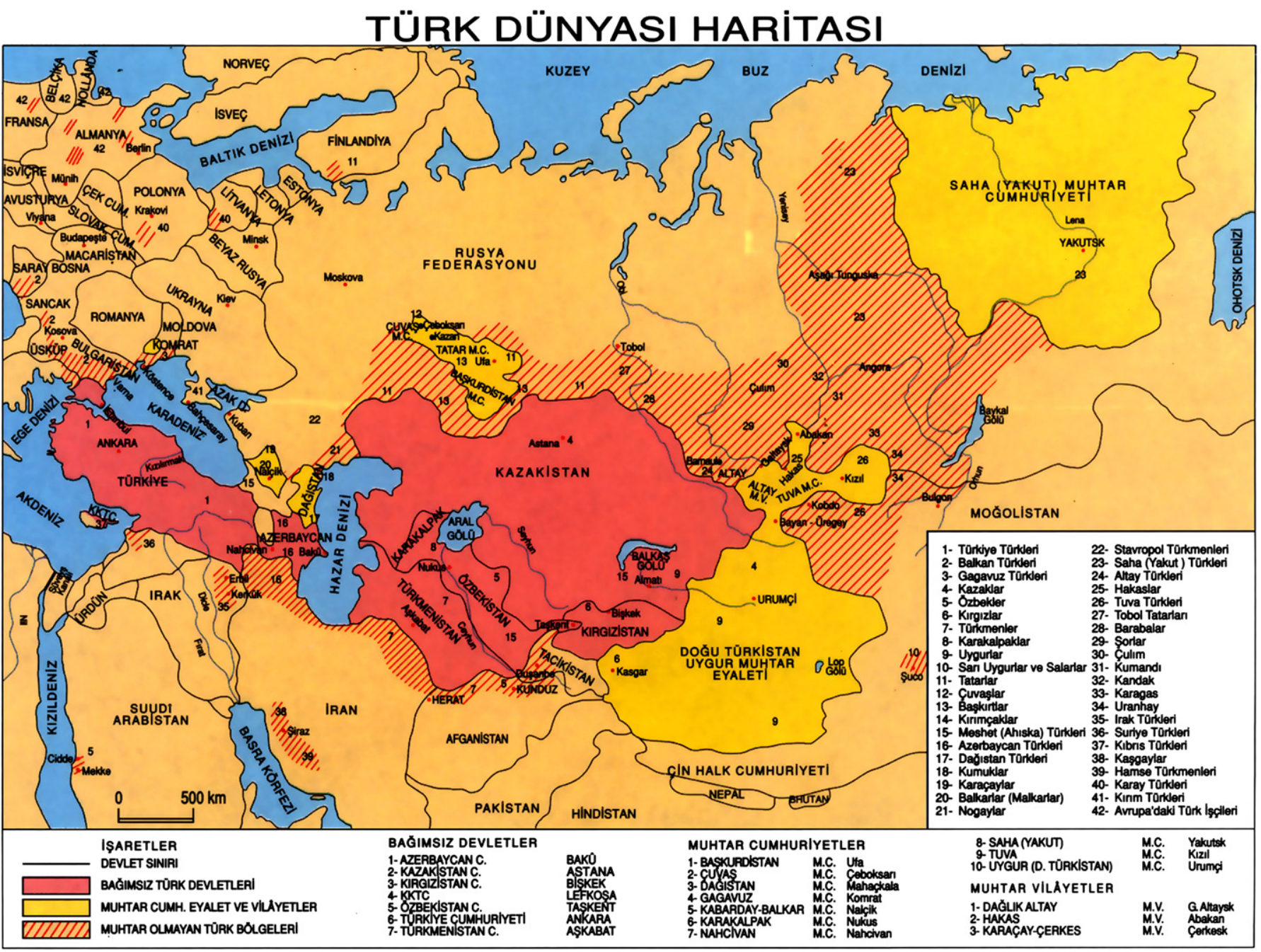

Fig. 3. "The Map of the Turkic World" (Ministry of Education, 1993b). 
becomes the foremost component of the Eurasian continent. Not only are distinct peoples living in various countries represented as a united body, but they also appear as the most populous body of people since China and India are virtually excluded from the map.

Interestingly, in addition to the emergence of the map of the Turkic world, the national maps included in the textbooks also went through a significant transformation in the 1990s (Fig. 4). The neighboring countries began to be identified with both their names as well as the borders separating them from each other. In the new maps, there is a visible effort to include Azerbaijan. Similar to the inclusion of the Aegean islands on the western part of the map, the map frame is used to contain at least a small portion of Azerbaijan. While the exclusion of mainland Greece accentuated the proximity of the islands to Turkey, the inclusion of even the name of Azerbaijan implies the closeness of the country to Turkey, geographically as well as politically.

Significantly, parallel to the inclusion of neighboring countries, the lines representing the latitudes and longitudes disappear. Previously, these cartographic codes were the only means locating the nation globally; now, the location is identifiable in the country's relationship with its neighbors. That is, while the latitudes and longitudes had worked as signs of global positioning within a hostile region of the globe, the inclusion of the names of the neighboring countries maintain connections and eradicate hostility, which in turn renders the cartographic codes irrelevant.

The maps included in school textbooks are products of official mapping; that is, they are cartographic representations controlled and disseminated by the state. In this regard, the relative liberalization of the textbook maps and the diminishing of the hostility they embody towards other nations in the first half of the 1990s illustrate the optimism of official nationalism resting on a neo-panTurkist perspective. However, as was mentioned earlier, the early 1990s also witnessed the rise of Kurdish separatism of the PKK which resulted in the rapid fading of such optimism and the rise of a racist-ethnicist nationalism advocating a military solution repression by force - to the Kurdish question (Bora, 2003: 436-437). Although the armed insurrection in Kurdish provinces had begun in 1984, it was fairly confined until the Gulf War in 1991. After the war, the power vacuum that emerged in Northern Iraq allowed the PKK to grow stronger. With a daily death toll of 8-10 soldiers, the Turkish government implemented new measures in the region and the Turkish military launched a wide-scale campaign that eventually extended into Northern Iraq. Between 1993 and 1995, wide-scale military operations were executed across the border. During this period, both human rights violations and anti-Kurdish nationalism intensified in Turkey. Mainstream media fueled the escalation of nationalism via dramatic reports on combat news and soldiers' funerals. A significant visual symbol of rising nationalism in popular media in this period was again the national map, only this time reproduced in the form of logo.

\section{Territory as national symbol: map-as-logo}

A favorite use of the map as a nationalist sign has been its production as a logo, isolated from its surrounding geographical context and implying a unity within its boundaries (Agnew, 1998; Edsall, 2007; Francaviglia, 1995). Such a representation visualizes almost all common aspects of nationalist ideologies; a clear-cut distinction between the interior (the nation) and the exterior (the others), and a homogeneous population of individuals sharing a harmonious way of life within the represented territory. The national map-as-logo, in this sense, easily turns into a cultural symbol of national identity (Edsall, 2007: 337). Anderson traces the origin of the map-as-logo to the practice of the imperial states of coloring their colonies on maps (Anderson, 1991: 175). This practice turned each of the colonies into a piece of a jigsaw puzzle detachable from its geographic context. This imagery allowed the map to transform into a pure sign that could easily be recognized

\section{TÜRKIYE HARITASI}

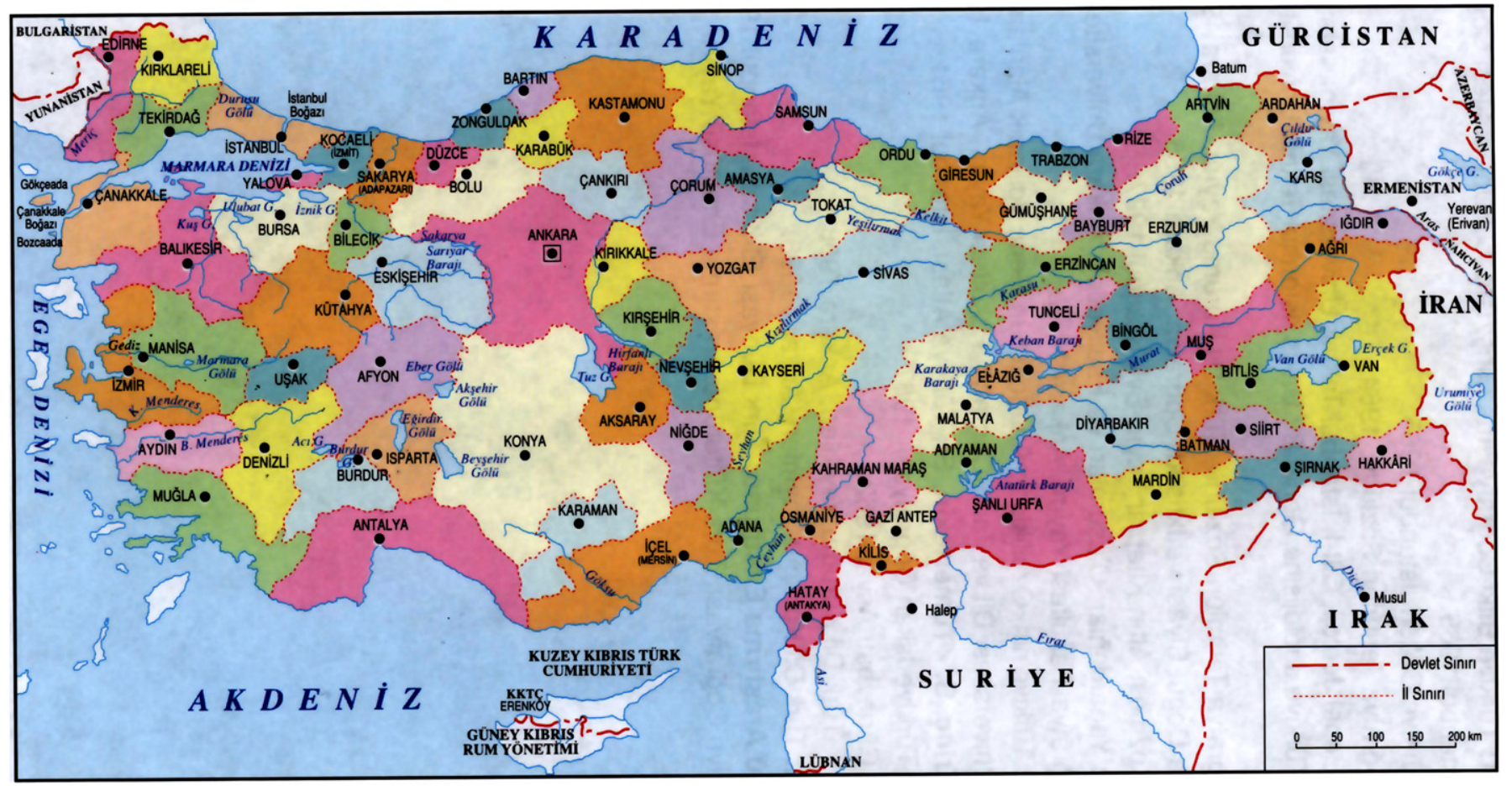

Fig. 4. "The Map of Turkey” (Erinç, 2001). 
and infinitely be reproduced within the popular imagination. It was later consumed by the emergent anticolonial nationalisms (Anderson, 1991: 175).

Within the Turkish context, the emergence of the national map as a logo occurred only in the 1990s, in the face of the intensifying Kurdish question. The most common use of the logo-map was the superimposition of its silhouette with the national flag. Colored red and containing a crescent and a star in the center, this flagmap logo quickly penetrated into popular imagination. For instance, two mainstream newspapers, Sabah and Akșam changed their logos into the map logo in 1993 and 1997, respectively. The use of the silhouette minimizes the map into the solidness and impenetrability of the outline and implies the homogeneity of its interior. Clearly, the monolithic fill emphasizes the distinction between the interior and the exterior and suppresses internal differences, suggesting uniformity and national pride (Edsall, 2007: 343).

The pervasiveness of the map-logo in various forms ranging from organizational logos and political posters to stickers and key chains can be understood in terms of banal nationalism. As Billig has argued, banal nationalism works with subtle reminders of nationhood, which are hardly noticed within everyday practices (Billig, 1995: 8). In this sense, the map-logo provides a good example of banal nationalism. It is reproduced in countless cultural forms within social life and it reminds the citizens of their place as national subjects. In cases embodying ethnic conflicts banal nationalism functions as a subtle way to assert hostility against minorities. In the case of Turkey, the map-logo serves as a familiar and continual sign to refute Kurdish identity.

Although the map-logo is an instrument of representing the nation as a unified body, the political iconography of the maps is not limited to the messages they serve to convey in accordance with the ideological preferences of their producers. There are also elements the map speaks of involuntarily, which could be defined as the "unconscious of the map". The Turkish map-logo provides an example for this idea. While the most important aspect of the maplogo is its depiction of the nation as a solid entity, the use of the crescent-and-star in the center of the map actually disturbs the homogeneity of the interior. It unconsciously differentiates the western and the eastern parts and highlights the very difference the logo tries to repress: the Kurdish identity of the eastern provinces. This unconscious attentiveness towards the directionality of the flag-map becomes particularly apparent when a third element is added to the map.

An interesting example illustrating the case is the cover page of an exhibition album published by the General Chief of Staff in 2007. The album assembled the exhibition photographs honoring the 125th anniversary of Kemal Atatürk's birth. The cover contained a portrait of Atatürk, a well-known dictum of his in his handwriting (Ne Mutlu Türküm Diyene! [How fortunate he who calls himself a Turk!]), the crescent-and-star of the Turkish flag in the background, and finally the flag-map as the central element of the composition (Fig. 5). Although the inclusion of Cyprus and the coloring of its northern part as an extension of Turkey attract attention, the striking component here is the seal of the General Chief of Staff on the map. The seal is imprinted to the left of the crescent, that is, on the western part of the country. The emptiness of the eastern part in contrast to the seal clarifies the geopolitical position of the Armed Forces. In contrast to the eastern part of the country, which was literally the battlefield in which it has been conducting operations for the last two decades, the Turkish army felt at home only in the west. Hence, the map-logo turns into the signifier of the very difference it serves to repress; although it is deployed to represent the nation as a homogeneous unity, it points to the difference between the eastern and western parts of the country.
The second example is a campaign ad designed for the 2009 local elections. The ad, which was circulated in Iskenderun in December 2008, endorsed the existing mayor for a second term in office. While the flag-map is again the central element in the ad, the mayor himself is seen on the upper left corner, rising behind the map and pointing his finger with a threatening gesture (Fig. 6). The line above the map reads "this country is ours", while bold letters in white across the map reads "love it or leave it!" The message appears as the mayor's own words, which is in tune with his intimidating gesture. The globally famous motto written across the map, which was originally invented in the US against those demonstrating against the Vietnam War, leaves the receiver of the message with two choices: to be assimilated or to be expelled. Significantly, this ultra-nationalist motto (which has become popular in Turkey in the mid-1990s) is divided into two phrases as it is located on the map. While the phrase on the western part of the map reads "love", the eastern part commands "leave!" It is hard to miss the geographical positioning of these textual messages on the map.

As illustrated with these two examples, the map-logo which emerged in the 1990s simultaneously emphasized a unified nation represented with solid borders and a nation inherently divided into western and eastern parts. The contradictory characteristic of the map-logo that was widely reproduced within popular culture has to be understood as a symptom of the dilemma of the general approach to the Kurdish question. On the one hand all political actors as well as the Turkish public desired a solution to the problem and an end to armed conflict. Yet, on the other hand, the dominant nationalist thread did not allow for a peaceful solution that required recognition of Kurdish identity.

\section{Mapping the Kurdish question across borders}

The Middle East map produced by Ralph Peters, discussed in the beginning of this article, became the cartographic signifier of a new phase of Turkish nationalism coping with the Kurdish question. Before, the issue was conceived within national borders; even though the PKK had bases in Northern Iraq, the power vacuum in the area allowed the Turkish military to freely conduct operations. That is, in terms of security, the territory was still seen as "interior". However, after 2003, the rapidly increasing influence of the Kurdish regional government among Kurds across the Middle East in general, prompted a new wave of anti-Kurdish nationalism in Turkish political discourse (Grigoriadis, 2006; Somer, 2004). Here, it has to be mentioned that the shift in the public perception of the Kurdish question in Turkey does not necessarily coincide with the actual developments regarding Kurdish autonomy in Iraq. The Kurdistan autonomous region was recognized as early as 1970 . Yet, in the wake of the 1991 Gulf War, the area became de facto independent. Finally, the fall of the Saddam regime in 2003 and the implementation of the new Iraqi constitution in 2005 resulted in the emergence of Iraqi Kurdistan as a federal entity recognized by Iraq and the United Nations.

For the part of the Turkish public, however, the period in which the Iraqi Kurds enjoyed de facto independence throughout the 1990s was marked by the military incursions of the Turkish army into Northern Iraq. In other words, the area was perceived as an extension of the Kurdish region of Turkey, in which the army freely conducted operations. The Turkish troops' penetration into Iraq in pursuit of PKK fighters throughout the mid-1990s resulted in the call of the PKK for a ceasefire in 1998. A year later, Abdullah Öcalan, the leader of the PKK, was apprehended. With these developments, the threat posed by the PKK to the Turkish state considerably diminished only to re-escalate after the fall of the Saddam regime in 2003. The Turkish Parliament's decision denying access to the US 


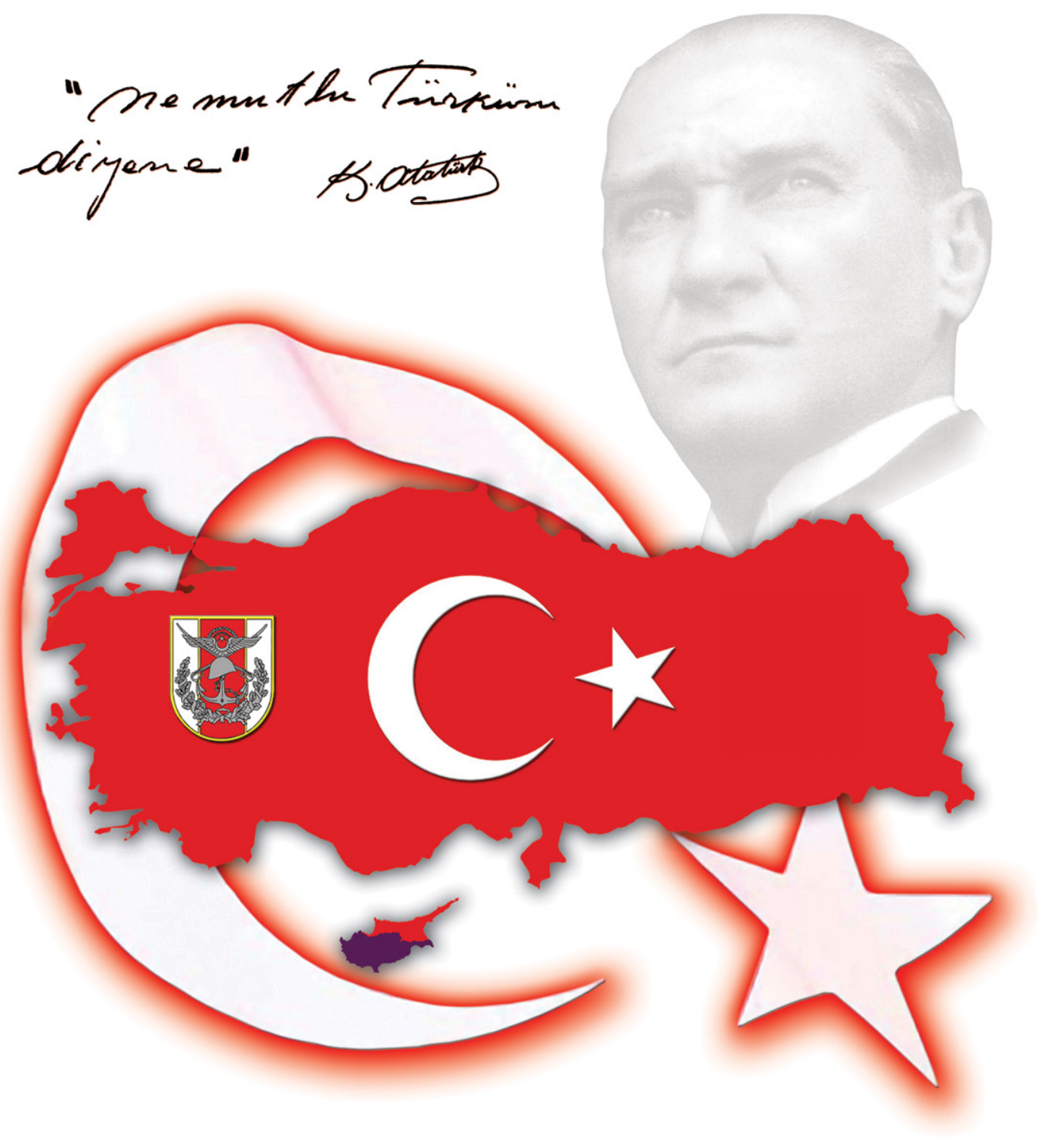

\title{
Geçmişten Günümüze Türkiye Cumhuriyeti
}

\author{
"Turkish Republic: Past and Present"
}

Fig. 5. The cover of Turkish Republic: Past and Present by the General Chief of Staff.

troops was retaliated by the US with the refusal to allow Turkey's military operations in Northern Iraq. This, in turn, created suitable grounds for the PKK to consolidate its power in the region. The organization lifted the ceasefire in 2004 and gradually escalated its operations with bombings in Turkish cities.

Within this context, the Turkish public realized for the first time the existence of a Kurdish political entity, which was now beyond the reach of the Turkish army. Moreover, Iraqi Kurdistan was now a focus of attraction for the Kurds in eastern Turkey with its rapidly increasing living standards. Hence, the threat from the Kurdish identity, which had been perceived as a domestic issue, was projected onto Northern Iraq, which now became impervious to Turkish military operations. The possibility of irredentist claims to the Kurdish region of Turkey from the Kurds in Northern Iraq as well as the escalating activities of the PKK across the border transformed the political imagination of the problem which, as we have seen, has frequently been constructed through maps.

In this regard, the Peters map triggered a traumatic confrontation on the part of the Turkish public. Since the military operations in mid-1990s resulted in the perception of Northern Iraq as an extension of eastern Anatolia, the Peters map reversed the identity of this unified (Kurdish) region. Now, it was gradually going under the cultural influence of the Kurdish regional government rather than the military control of the Turkish state. It was as if the map visualized concrete territorial claims raised by the Iraqi Kurds to annex eastern Turkey.

When Cumhuriyet brought the map to the public agenda and turned it into a major issue provoking anti-American sentiments, 


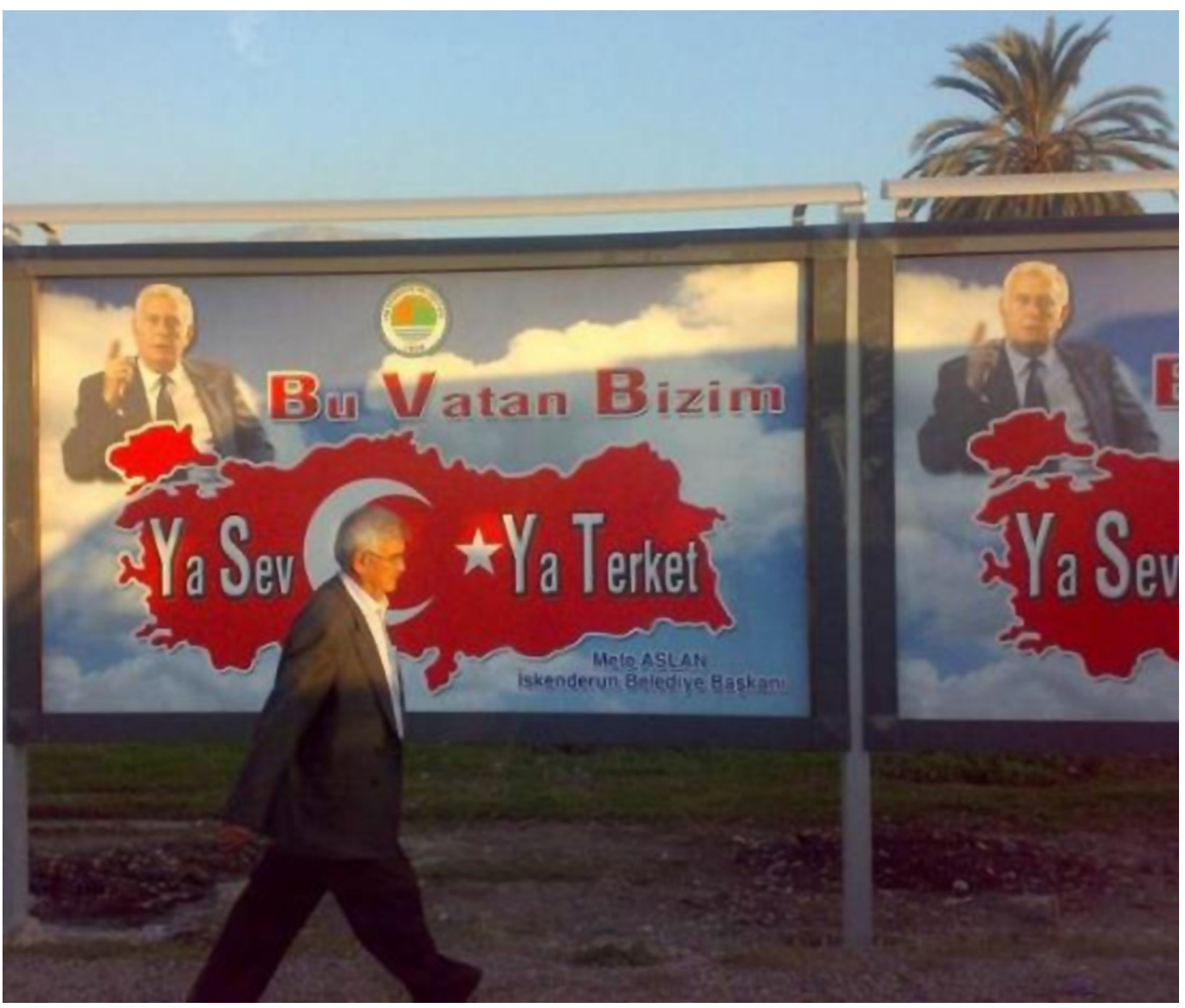

Fig. 6. “Love it or Leave it!" Radikal, December 3rd 2008.

protests were raised by various actors. In October 2006, Ataturkist Thought Association, a major civil organization promoting Kemalist ideology launched a signature campaign against the Peters map (Hürriyet, October 16th 2006). In July 2007, a few weeks prior to the early general elections, Hürriyet published news of an incident that occurred in an international military meeting in Athens, which soon became a hot topic. Accordingly, Yannis Mezis, a professor and an analyst working for the Greek Defense Analysis Institute showed the Peters map during his presentation, and discussed the overreaction of the Turkish public. However, Turkish military officers participating in the event protested and left the meeting (Hürriyet, July 7th 2007). Although the professor apologized a few days later and claimed that he was not propagating the map but discussing the public response to it, the news itself was agitating enough for the Turkish audience. The online version of the news published on Hürriyet's website received 220 reader responses in a day, each of which illustrated the nationalist rage against the map (not to mention the fact that it was a Greek official referring to it).

Here, it is necessary to briefly discuss the newspapers mentioned above. In contrast to Cumhuriyet, which is the voice of the state elite and promotes official nationalism, Hürriyet, the mostwidely circulated Turkish newspaper, functions as a powerful instrument in maintaining ideological hegemony balancing the views of the bourgeoisie and the military. Although it never resorts to traditional right-wing nationalist arguments, Hürriyet is a major medium disseminating subtle messages of "liberal neonationalism". This discourse "explains national pride, not through the nation's unique, authentic characteristics but through its capacity to harmonize with universal standards", affirming globalization and emphasizing economic prosperity (Bora, 2003: 440-445). Hürriyet has also been a powerful vehicle in constructing the political representation of the Kurdish question in Turkey (Bayındır, 2007).

If we turn to the responses to the Peters map, an important aspect was its deployment as a means to attack the moderate Islamist Justice and Development Party (JDP) government, which was labeled by the nationalist parties as a collaborator of US imperialism. Here, it should be noted that the rise of nationalist sentiments after 2003 also targeted the JDP, which was portrayed by the nationalist opposition as the collaborator of the US conspiracy to establish a free Kurdish state. A major reason for this was the fact that the JDP was the only party receiving votes from the eastern provinces aside from the pro-Kurdish Democratic Society Party indirectly associated with the PKK. Especially late 2006 and early 2007 saw a massive anti-JDP campaign to force the government to call for early general elections before the presidential elections in the spring of 2007. ${ }^{1}$ Hence, the nationalist campaign widely utilizing the flag-map logo as an ideological symbol throughout 2006-2007 was also as an action against the JDP.

On the same day with the news regarding the incident in Athens, the local branch of the oppositional Republican People's Party in Erzurum (a city known to be a nationalist base) circulated ads presenting the Peters map as an illustration of the US proposal for the "Greater Middle East" (Hürriyet, July 7th 2007). The ad claimed that Prime Minister Erdoğan was the co-chair of the "Greater Middle East Project", and the map was the actual proposal of the project for a future Middle East. Moreover, it was falsely claimed that the map left Erzurum to Armenia. Although Peters' map did 
not indicate Erzurum, a simple comparison with any national map indicating the location of the city would reveal that the city rested either in Turkey or the imaginary Kurdistan. Nevertheless, it must have sounded more provocative for the city to be a part of Armenia for those who designed the ad. The JDP responded by going to court (Hürriyet, July 13th 2007).

\section{Old ideologies, new technologies: appropriation as mapmaking}

The most interesting reactions to the Peters map were those that assumed cartographic forms. Alternative maps of the Middle East rapidly began to circulate especially on the Internet. These "appropriated maps" were produced digitally through the reworking of random maps found on the Internet. Fashioned by ultra-nationalist individuals, appropriated maps always expanded the territory of Turkey. In their modest versions, Northern Iraq including Mosul, Kirkuk and Erbil, all of Armenia, as well as Cyprus and the Greek islands in the Aegean Sea were incorporated into Turkey. In bolder versions, a larger portion of Iraq together with a considerable section of Syria including Aleppo were annexed, the eastern frontier was expanded to include territory from Iran, Armenia and Azerbaijan, and the western border was moved further to integrate Western Thrace including Salonica. These maps were easily produced and widely circulated via email lists and Internet forums (Fig. 7).

The reproduction of power relations through cartographic means has been discussed in various studies. Among these, there is a considerable body of work related to forms of resistance; either in the sense of resistance to cartographic power or cartographies of resistance (Crampton, 2001: 234-236). While some scholars have scrutinized the alternative political effects of maps on the part of the subordinate groups (Helgerson, 1992), others have discussed the subversive effects of the maps produced by indigenous peoples with inquiries informed by postcolonial studies (Godlewska \& Smith, 1994; Jacobs, 1996: 132-156; Sparke, 1998). These studies underlined the counterhegemonic potentials of the production and circulation of alternative maps which troubled the cartographic hegemony of (colonial) state power. The appropriated maps that I discuss here are related to these examples as they generate alternative representations to the conventional depiction of a particular geography. However, they also differ drastically since the appropriated maps do not operate counter to either the dominant modes of cartographic representation or the ideological meanings they produce. On the contrary, they serve to extend state-sponsored nationalism to irredentist and at times racist extremes through cartography. This is also visible in their rapid institutionalization, which, as I will discuss below, occurred through the mass reproduction of electronically produced appropriated maps in print forms by various organizations.

The practice of appropriating existing maps and altering their content is significant in two senses. First of all, such practice expands the definition of "popular cartography" in terms of agency. It was earlier mentioned that popular cartography is generally understood as the maps produced for masses and circulated through the mass media (Kosonen, 2008: 22). Examples of popular cartography range from weather maps in newspapers to tourist maps and road maps. Although popular maps are widely circulated and reach large numbers of people, there is a clear distinction between their producers and their users. Yet, in the case of the appropriated maps, the ordinary receiver of the map becomes a mapmaker since every producer of a new map is the receiver of the earlier version of the map s/he reworks. The requirements for this practice are familiarity with an image-processing software and access to the Internet. A quick web search for Middle East maps provides innumerable samples to rework. The user simply fills the territories to be "annexed" with red, and the map transforms into a totally new one. The city and country names might require translation according to the intended audience. The second significant point is the epistemological status of the appropriated map, since it abandons its claim to represent the objective truth of the existing geopolitical situation. The relation of the map to "reality" - that is, the existing national borders - becomes irrelevant; it now represents an irredentist desire to enlarge the national territory. Nevertheless, these appropriated maps should not be understood simply as false cartographic representations. They refer to a historical document, Misak-ı Milli (national oath), that provides them legitimacy in terms of ideological authority as well as epistemological validity.

Misak-ı Milli was originally a resolution passed by the last Ottoman Parliament on January 28th 1920; that is, between the ceasefire after World War I and before the signing of the Treaty of Sevres. The six-item resolution declared the territories which were unoccupied by the time of the ceasefire in 1918 as the homeland of Turks and demanded plebiscites for the Arab-inhabited territories and Western Thrace. Although the resolution did not provide definite borders, it was the major reference of the nationalists pursuing the War of Independence in 1919-1922. This historic document became the reference point for the appropriated maps produced by Turkish nationalists creating and circulating them. It is

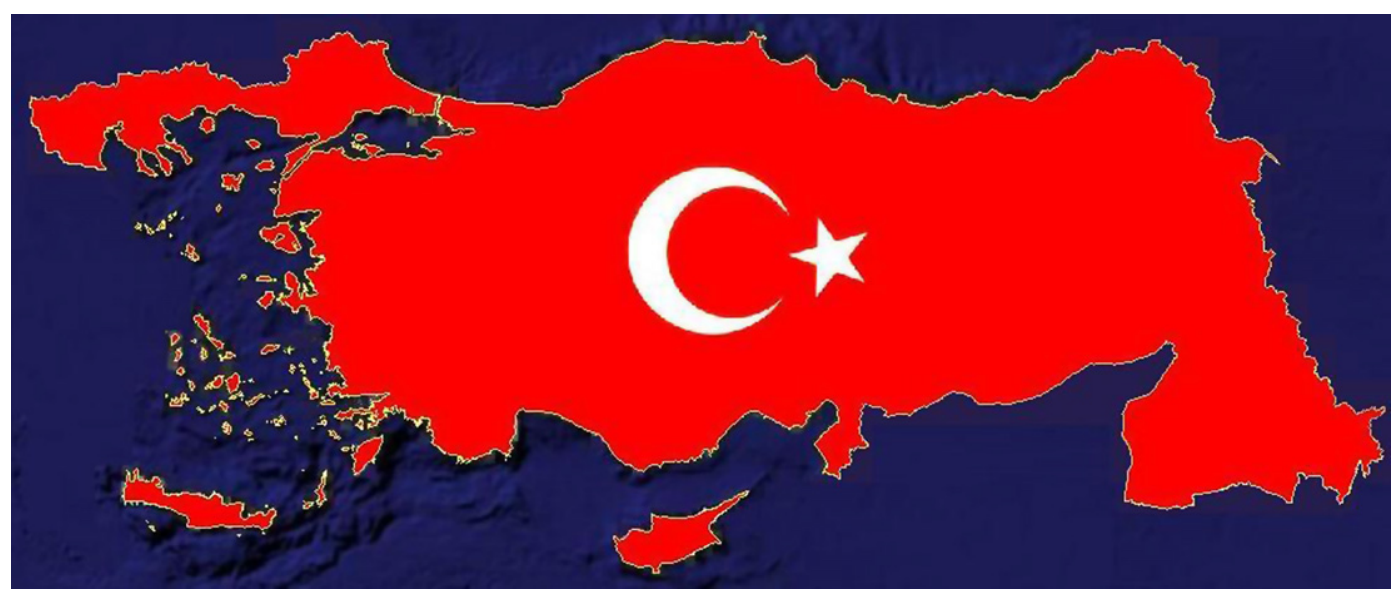

Fig. 7. A map-logo circulating on the World Wide Web as an illustration of "Misak-1 Milli". 
crucial to note that these irredentist maps by no means represent the claims of the Misak-ı Milli document; yet they construct their validity with reference to this document. In other words, they do not claim to represent an existing geopolitical situation but put forward a political claim supported by the distorted representation of a historical document.

In addition to the ultra-nationalist websites, even mainstream forums used by Turkish participants became stages for the production, circulation and discussion of appropriated maps. For instance, a number of topics related to the map incident - the Peters map - were opened within the website wowturkey.com in 2007. The site, which was originally established for exchanging scenic pictures of Turkey, had 193,517 registered users as of June 15th 2009. The main topic addressing the issue was created on April 25th 2007, with the heading "How do you like our new map?" and an opening post including a map similar to Fig. 7. (http://wowturkey.com/ forum/viewtopic.php?t=40486\&start $=0$ ). The topic received 283 messages from 221 different users and it was viewed 34,761 times by June 2009. Most of the commentators were fond of the map enlarging Turkish borders while a few protested such expansionist views provoking hostility towards neighboring nations. Different users also produced their versions of enlarged Turkey, and interestingly, a number of relatively amateur users requested help in producing such maps.

The production and dissemination of such expansionist maps on the Internet soon led to their production in print form as well. In January 2007, the local branch of the right-wing True Path Party in
Ballkesir published 1000 copies of a map expanding the TurkishIraqi border to the south, invoking the Turkish claims to Northern Iraq in the 1920s (Hürriyet, January 21st 2007). The party officials visited houses and workplaces and handed out copies of the map, and finally requested the Ministry of Education to include the map within school textbooks. Similarly, in February 2008, Türkiye Kamu-Sen, the confederation bringing together twelve nationalist trade unions reproduced a map entitled Misak-ı Milli in order to distribute to its 400,000 members (Fig. 8). The expanded borders of Turkey were again filled red and contained the crescent-and-star of the Turkish flag. A portrait of Kemal Atatürk was also located within the crescent, significantly in his military costume invoking the War of Independence. The map was an appropriated map, which is evident in the clumsily drawn Turkish-Syrian border. Yet, it was reproduced and distributed nation-wide. The subtitle below the map declared: "We will never give up our devotion to Misak-1 Milli". The same map was very recently sent to the Kurdish deputies of the Democratic Society Party as an intimidating gesture by the ultra-nationalist Alperen Ocakları (Radikal, June 11th 2009).

As mentioned above, the original resolution of the Misak-ı Milli did not include clear borders; moreover, aside from claiming the disputed territories, it - rather modestly - requested plebiscites for them. In the 2000s, however, the actual historical document is visually reproduced with a significant distortion to its political claims. The reproduction of the appropriated maps with reference to Misak-ı Milli not only provides historical support to the ideological claims they represent, but also convinces the Turkish public

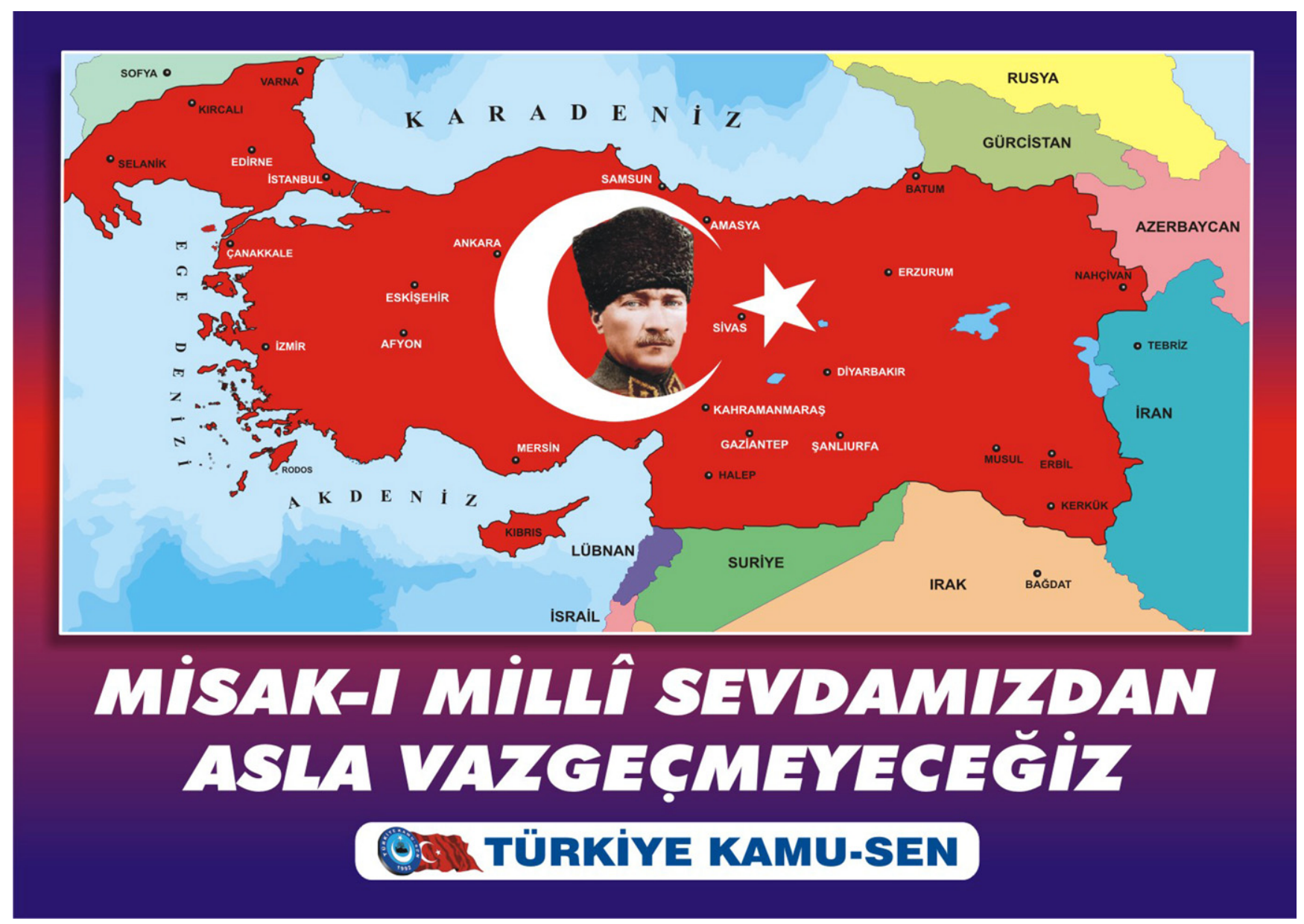

Fig. 8. The "Misak-1 Milli” map of Türkiye Kamu-Sen. 
that these maps accurately represent the historical document. In other words, the map, which is supposed to visualize the statements of the text, reverses the relation. With its power to convince the observer, the map is what shows us the true content of the national oath; the resolution becomes merely a supplementary note attached to the map.

It is interesting to note that the circulation of Misak-ı Milli maps is not limited to the Turkish public. The "Misak-1 Milli" item in the English version of Wikipedia includes a similar appropriated map as an illustration of the historical document presented on the web page. Unsurprisingly, the map was produced by a Turkish user in February 2007, and it was disputed by other users. The map existed as of June 15th 2009 (http://en.wikipedia.org/wiki/Misak-1_Milli).

The crucial implication of such ideological distortion of historical facts was obviously related to the Kurdish territory in Northern Iraq; the appropriated maps served as the proof that Turkey had (historical) rights to this territory. It was mentioned earlier that the PKK operations gradually escalated after 2004. Within this context, columnists in the mainstream media began to discuss the irrelevance of existing Turkish-Iraqi border with its incompatibility with the geographical qualities of the terrain. It was argued that the mountainous character of the area made it easy for infiltrations across the border and the security of the border would be much easier to provide if it was moved $30-50 \mathrm{~km}$ to the south. A dramatic incident to fuel these arguments was the PKK attack on a military post only a few kilometers inside the border, killing 12 soldiers and wounding 16 others on October 21st 2007. The Armed Forces and the oppositional parties put pressure on the government to launch a cross-border incursion; however, the US authorities denied approval. It was only in mid-December that the Turkish and the US governments agreed on an air strike, and Turkish troops initiated a limited land operation in February. In the meantime, the Turkish public was furiously discussing an invasion, with the claims that the Kurdish government in Northern Iraq sheltered the PKK (Özkök, 2007). Within this political climate, the idea of changing the border sounded quite relevant and found supporters (Akyol, 2007a, 2007b).

The interesting point, here, is the emergence of a new mode of cartographic representation in reporting the PKK attack in October. Images retrieved from Google Earth were used by almost all newspapers to illustrate the event. The foremost quality of this mode of representation that led the newspapers to utilize it is its "realistic" depiction owing to the use of satellite images. It is also important that the availability of "virtual globe" software systems democratizes the production of cartographic representations through accessibility and interactivity (Sheppard \& Cizek, 2009). They are open to appropriation and allow users to exploit the data for further production of visualizations. In the case under discussion, the Turkish media extensively used Google Earth images to report both the PKK attack and the air strike conducted by the Turkish military in the following months.

A striking example of such use was Hürriyet's "photo-analysis" of the attack published on the newspaper's website (Demir, 2007). Composed of 90 images retrieved from Google Earth, the analysis visually described the area and the geographical conditions which are advantageous to PKK infiltrations across the border. The images

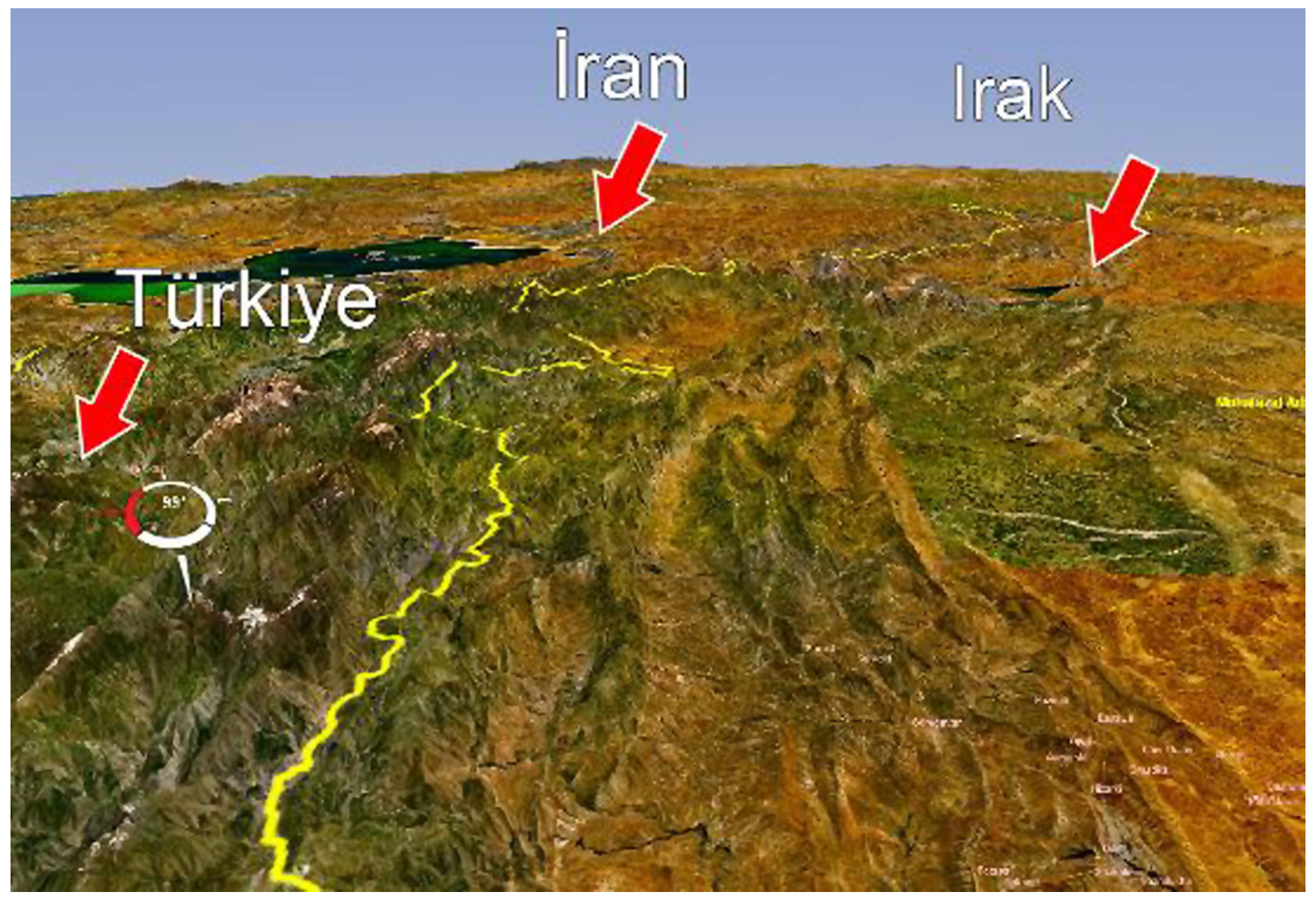

Fig. 9. Google Earth image showing the Turkish-Iraqi border. (Demir, 2007: [1]). 
were carefully selected to depict the mountainous terrain at the intersection of the borders between Turkey, Syria, Iraq and Iran. They aimed to prove that the actual borders were incompatible with the terrain (Fig. 9). The geographical elements; the mountains facing two different countries on its two sides, valleys cutting through borders, and the Zap creek disturbing the border with its irregular basin witnessed the impossibility of securing the border. The observer is convinced that the terrain has to be conceived with respect to the hilltops, slopes, plains and depressions, represented with white, brown, green and yellow in the images. Within this mingling of colors, the thin yellow line representing the border is a self-sufficient signifier of its irrelevance. To support this impression, angular views were also used as landscape images. In addition to the careful selection of 3D views, they were also reworked with the insertion of labels and arrows to make the countries identifiable. The representation of the region in the form of a continuous terrain forces the publishers to introduce visual signs as well as explanatory notes to avoid confusion for the part of the ordinary viewer. In this respect, the 3D Google Earth views also become appropriated images conveying a particular message: the terrain conditions required revision of the frontier, which should be moved to the southern plains. To put it differently, the geography required the Turkish territory to be expanded as witnessed by the indisputable authority of cartography.

\section{Conclusion}

Nationalism as a political discourse requiring a fundamental connection to a particular territory has constantly referred to maps as evidence of the permanent existence of the respective nation. In the case of modern Turkey, the national map has been a symptomatic signifier of a constant anxiety of territorial loss. Built around such anxiety, Turkish nationalism has always been sensitive towards the borders defining the national territory.

In this article, I have shown the production of nationalist sentiments through the use of maps in Turkey. National maps have been major tools for constructing a particular image of the nation with geopolitical implications. During the Cold War, the maps included in Turkish school textbooks, which were the products of official cartography, presented a country surrounded by hostile neighbors on all sides. Yet what was more important than this particular representation was the surplus effect of these maps, which I have defined as cartographic awareness. The familiarity with the national map as a result of its recurrent existence in textbooks and on classroom walls led to its detachment from the specialized domain of cartography. The transformation of the national map into a mundane image has been crucial in the emergence of map-as-logo, which was invented and put into circulation to represent a unified nation in the face of the Kurdish question in the 1990s. In this regard, the cartographic awareness generated by the national maps in school textbooks represents a link between official cartography and popular cartography. The wide-scale and wide-ranging use of the national map-as-logo in the 1990s illustrates how the map becomes open to new iconographies via signs and symbols attached to it, once it enters the domain of popular culture. The superimposition of the logo-map in particular and the crescent-and-star of the Turkish flag exemplifies the multiple and even conflicting meanings generated by the same image.

Finally, I have discussed the emergence of appropriated maps, which I maintain expands the definition of popular cartography in terms of cartographic agency. With the help of computer software, ordinary people have been able to produce their own maps by appropriating other maps available on the Internet. The emergence and the rapid spread of appropriated maps are a cartographic response to a new phase of the Kurdish question. More importantly, this was a response to a particular map which was the product of the imagination of a retired US Army officer. The significance of the Peters map, which simply redesigned the national borders in the Middle East, is that it set off a cartographic imagination which went beyond a mere understanding of the map as the signifier of an actual geopolitical situation. In other words, it made it possible to imagine maps which reflected the geopolitical aspirations of ordinary people who, with the help of digital technologies, transform from map users into mapmakers.

\section{Endnotes}

${ }^{1}$ It was intended to prevent JDP from electing the president single-handedly due to its majority in the parliament. Even the Armed Forces published an online ultimatum against the candidacy of an Islamist politician for president. The presidential elections were deadlocked with the intervention of the Supreme Court and the government called for early elections to be held in July. Nevertheless the elections were another victory for the JDP, and Abdullah Gül, the former Minister of Foreign Affair was elected president in August.

\section{References}

Agnew, J. (1998). Geopolitics. London: Routledge.

Akyol, T. (October 22nd 2007a). Bu Sinır Savunulamaz. [This border cannot be defended]. Milliyet.

Akyol, T. (October 23rd 2007b). Irak Sınırını Düzeltmek. [Fixing the Iraqi border]. Milliyet.

Anderson, B. (1991). Imagined communities. London/New York: Verso. pp. $170-178$.

Bali, R. N. (2006). The politics of Turkification during the single party period. In H. Kieser (Ed.), Turkey beyond nationalism: Towards post-nationalist identities (pp. 43-49). New York: Macmillan.

Bașkaya, F. (1991). Paradigmanın Iflası: Resmi Ideolojinin Elestirisine Giris. [The Bankruptcy of the paradigm: Introduction to the critique of the official ideology]. İstanbul: Doz. p. 53.

Bayındır, Ö (2007). Representation of the Kurdish question in Hürriyet and Cumhuriyet (1990-2006). Unpublished Master's thesis. Middle East Technical University Department of Sociology.

Billig, M. (1995). Banal nationalism. London: Sage. pp. 8, 38.

Birkan, A. (1988). Ortaokullarda Dilbilgisi Dersleri. [Grammar Lectures for secondary schools]. İstanbul: Eko.

Bora, T. (2003). Nationalist discourses in Turkey. The South Atlantic Quarterly, 102 $(2-3), 433-451$

Crampton, J. W. (2001). Maps as social constructions: power, communication and visualization. Progress in Human Geography, 25, 235-252.

Culcasi, K. (2006). Cartographically constructing Kurdistan within geopolitical and Orientalist discourses. Political Geography, 25, 680-706.

Çelebi, Y.I. (2006). Turkey's energy policies and the Eurasian region. Unpublished Master's thesis. Ankara: Middle East Technical University, Department of International Relations. p. 66.

Demir, A. (2007). PKK'nın Geçis Noktaları ve Kampları. [PKK's infiltration points and base camps]. Hürriyet on-line. http://fotoanaliz.hurriyet.com.tr/GaleriDetay. aspx?cid=7013\&p=1\&rid=4369. Accessed 16.06.09.

Edney, M. (1997). Mapping an empire: The geographical construction of British India, 1765-1843. Chicago: University of Chicago Press.

Edsall, R. M. (2007). Iconic maps in American political discourse. Cartographica, 42 (4), 335-347.

Erinç, S. (2001). Lise Coğrafya Ders Kitabı. [Geography textbook for high schools]. İstanbul: Altın Kitaplar.

Francaviglia, R. F. (1995). The shape of Texas: Maps and metaphors. College Station: Texas A\&M Press.

Godlewska, A., \& Smith, N. (Eds.). (1994). Geography and empire. Cambridge, MA: Blackwell.

Grigoriadis, I. N. (2006). Upsurge amidst political uncertainty: Nationalism in post2004 Turkey. SWP Research Paper, RP 11, October 2006.

Guida, M. (2003). The Sèvres syndrome and "Komplo" theories in the Islamist and Secular Press. Turkish Studies, 9(1), 37-52.

Gürleyen, F. I. (1998). The ideology and textbooks: “Turkish republic history of Renovation and Ataturkism" textbooks (1980-1990). Unpublished Master's thesis. Bilkent University.

Harley, J. B. (1988). Maps, knowledge, and power. In D. Cosgrove, \& S. Daniels (Eds.), The iconography of landscape: Essays on the symbolic representation, design, and use of past environments (pp. 277-312). Cambridge: Cambridge University Press.

Harley, J. B. (1989). Deconstructing the map. Cartographica, 26(2), 1-20.

Harley, J. B. (1990). Cartography, ethics and social theory. Cartographica, 27(2), 1-23.

Helgerson, R. (1992). Forms of Nationhood: The Elizabethan writing of England. Chicago: University of Chicago Press. pp. 107-147. 
234

B. Batuman / Political Geography 29 (2010) 220-234

Herb, G. (2004). Double vision: territorial strategies in the construction of National identities in Germany, 1949-1979. Annals of the Association of American Geograpers, 94(1), 140-164.

Hu, B. (2007). Cultural images: reflection of political power in the maps of Chinese administrative Gazetteers of the Song Dynasty (960-1279 CE). Cartographic 42(4), 319-334.

Jacobs, J. M. (1996). Edge of empire: Postcolonialism and the city. London: Rutledge. pp. $132-156$.

Kosonen, K. (1999). Maps, newspapers, and nationalism: the Finnish historical experience. GeoJournal, 48(2), 91-100.

Kosonen, K. (2008). Making maps and mental images: Finnish Press cartography in Nation-building, 1899-1942. National Identities, 10(1), 21-47.

Ministry of Education. (May 29th 1993a). Mill Eğitim Bakanlı̆̆ı Der Kitapları Yönetmeliği. [Ministry of education decree on school textbooks]. Resmi Gazete, 21595, 7-15.

Ministry of Education. (1993b). Türk Dill ve Edebiyatı, Edebiyat IV [Turkish language and literature IV]. İstanbul: Ilıcak.

Ministry of Education, Youth and Sports. (September 7th 1985). Milli Eğitim Gençlik ve Spar Bakanlığı'na Bağlı Okullarda Okutulacak Kitaplar Hakkında Yönetmelik [Decree regarding the textbooks to be used in schools overseen by the Ministry of Education, Youth and Sports]. Resmi Gazete, 18861, 9-13.

Monmonier, M. (1996). How to lie with maps (and ed.). Chicago: University of Chicago Press.

Özcan, A. K. (2006). Turkey's Kurds: A theoretical analysis of the PKK and Abdullah Öcalan. London: Routledge. pp. 54-72, 63-83.

Özkök, E. (October 22nd 2007). 3-5 F16; 30-40 Sorti. Hürriyet.
Parsi, A. (1996). Territories, boundaries and consciousness: The changing geographies of the Finnish-Russian border. Chichester: John Wiley \& Sons. pp. 145-151.

Peckham, R. S. (2000). Map mania: nationalism and the politics of place in Greece, 1870-1922. Political Geography, 19, 77-95.

Peters, R. (June 2006). Blood borders: how a better Middle East would look. Armed Forces Journal. http://www.armedforcesjournal.com/2006/06/1833899/. Accessed 09.08.09.

Pickles, J. (1992). Texts, hermeneutics and propaganda maps. In T. J. Barnes, \& J. S. Duncan (Eds.), Writing worlds: Discourse, text and metaphor in the reprosentation of landscape (pp. 193-230). London: Routledge.

Robins, P. (2003). Suits and uniforms: Turkish foreign policy since the Cold War. London: Hurst \& Co. Publishers. pp. 161-180.

Sheppard, S. R. J., \& Cizek, P. (2009). The ethics of Google Earth: crossing thresholds from spatial data to landscape visualization. Journal of Environmental Managemont, 90, 2102-2117.

Sorer, M. (2004). Turkey's Kurdish conflict: changing context, and domestic and regional implications. The Middle East Journal, 58(2), 235-254.

Smith, A. D. (1991). National identity. Reno, Nevada: University of Nevada Press. pp. 8-10.

Sparker, M. (1998). The map that roared and an original atlas: Canada, cartography and the narration of nation. Annals of the Association of American Geographers, 88(3), 463-495.

Uslu, N. (Fall \& Winter, 2003). The Russian, Caucasian and central Asian aspects of Turkish foreign policy in the post-cold war period. Alternatives: Turkish Journal of International Relations, 2, 3-4, 164-187.

Wood, D. (1992). The power of maps. New York: Guilford Press. 